\title{
Perancang Alat Sistem Monitoring Volume Air Pada Tangki Air Berbasis Telegram Dengan Mikrokontroler NodeMCU
}

\author{
The Designer of The Water Volume Monitoring System on \\ Telegram-Based Water Tank with NodeMCU Microcontroller
}

\author{
Junaldi, Titin Ritmi \& Adityo Ferry \\ Jurusan Teknik Elektro Politeknik Negeri Padang Kampus Limau Manis Padang 25163 \\ Telp.0751-72590 Fax.0751-72576 Email : junaldi@pnp.ac.id, titinritmi@ @np.ac.id, \\ adityo.ferry@gmail.com
}

\begin{abstract}
At this time the world is experiencing a Covid-19 outbreak which has resulted in all activities being restricted and must implement health protocols to prevent the transmission of the corona virus. One of these health protocols is washing hands regularly. Padang State Polytechnic is an educational institution that applies health protocols by providing water tanks in several places so that everyone who comes to Padang State Polytechnic can wash their hands easily. The water tank available at the Padang State Polytechnic does not have a specific schedule for filling it. This causes the officer in charge to always check the condition of the water tank. At the Padang State Polytechnic, the number of water tanks available is not small. Periodic inspection of the water tank becomes ineffective and causes not all of the water to be fully filled or that there is also a tank that is not filled. Therefore, the Water Volume Monitoring System tool in a Telegram Based Water Tank with a NodeMCU Microcontroller can make it easier for officers to monitor the state of the water via telegram so that the water tank monitoring process at Padang State Polytechnic becomes more effective. The water volume monitoring system tool is built with NodeMCU Microcontroller technology and the Telegram application to check notifications.
\end{abstract}

Keywords: Water Tank, Monitoring, Microcontroller, NodeMCU, Telegram

\section{PENDAHULUAN}

Penyakit virus COVID-19 adalah penyakit menular yang disebabkan oleh virus corona yang baru-baru ini ditemukan. Virus yang menyebabkan COVID-19 terutama ditransmisikan melalui droplet (tetesan kecil) yang dihasilkan dapat tertular saat menghirup udara yang mengandung virus ketika kita terlalu dekat dengan orang yang sudah terinfeksi COVID-19. Kita juga dapat tertular saat menyentuh permukaan benda yang terkontaminasi lalu menyentuh mata, hidung, atau mulut.

Dalam hal ini diperlukan penerapan protocol kesehatan untuk mencegah penularan virus tersebut . Salah satu penerapan protocol kesehatan yang harus dilakukan adalah sering melakukan cuci tangan. Dalam hal ini air merupakan kebutuhan yang sangat vital bagi kehidupan manusia.Karena itu jika kebutuhan akan air tersebut belum tercukupi maka dapat memberikan dampak yang besar terhadap kerawanan kesehatan maupun sosial. Dengan adanya dampak pandemic COVID-19 ini, maka kampus Politeknik Negeri Padang menerapkan protocol kesehatan dengan menyediakan tangki air untuk melakukan cuci tangan.

Tangki air yang tersedia di Politeknik Negeri Padang, tidak memiliki jadwal khusus dalam pengisiannya. Hal ini menyebabkan petugas yang bertanggung jawab harus selalu memeriksa keadaan tangki air tersebut secara berkala. Pada Politeknik Negeri Padang jumlah tangki air yang tersedia tidak sedikit. Pemeriksaan 
tangki air secara berkala menjadi tidak efektif dan menyebabkan tidak semua air terisi penuh atau ada juga tangki yang tidak ada isinya.

Adapun tujuan dari penelitian ini adalah :

1. Merancang alat monitoring volume air pada tangki air cuci tangan.

2. Mengimplementasikan alat monitoring volume air pada tangki air cuci tangan.

3. Menguji alat monitoring volume kapasitas air pada tangki air cuci tangan.

4. Mendapatkan pemberitahuan pada smartphone melalui aplikasi Telegram.

Batasan dalam penelitian ini adalah :

1. Alat ini dirancang dalam bentuk prototype menggunakan komponen utama yaitu NodeMCU sebagai wadah untuk mengendalikan komponen lain yang akan

2. Digunakan Sensor Ultrasonik untuk mengukur volume air di dalam tangki. Pompa air DC untuk mempompakan air ketangki.

3. Alat penghitung volume air pada tangki air cuci tangan menggunakan NodeMCU sebagai mikrokontroller.

4. Monitoring air menggunakan aplikasi telegram yang akan menampilkan volume, serta menambahkan fitur pemberitahuan pengisian air.

5. Kecepatan air yang masuk ke dalam tangki tidak ditentukan.

6. Pompa air DC diletakan pada sumber air.

7. Relay, sensor ultrasonik, nodeMCU diletakan diatas tangki air.

8. Alat yang digunakan untuk membangun prototype ini terdiri dari hardware laptop, nodeMCU, kabel jumper, smartphone, sensor ultrasonik, relay modul, pompaair DC, micro usb, lcdi2c, project board, led, resistor 220 OHM, buzzer, battery 9 Volt, socket battery, dan software yang digunakan berupa windows 10, aplikasi telegram, arduino IDE, PHP, dan Android.

9. Sistem kerja prototype ini pada saat air berada pada level terendah maka, notifikasi pemberitahuan kepada petugas untuk segera mengisi air terkirim melalui aplikasi telegram, dan pada saat air berada pada level tertinggi, notifikasi diterima oleh petugas melalui aplikasi telegram.

10. Untuk menggunakan aplikasi telegram ini pada android dibutuhkan versi minimal dari sebuah type android tersebut, type yang dibutuhkan untuk menginstall aplikasi telegram ini menggunakan versi Ice Cream Sandwich (Android 4.0) ke atas.

11. Alat monitoring kapasitas tangki air ini dapat mengirimkan notifikasi otomatis saat pada level air terendah ke smartphone petugas melalui aplikasi telegram.

\section{Teknologi IoT}

Internet of Things (IoT) adalah sebuah konsep/skenario dimana suatu objek yang memiliki kemampuan untuk mentransfer data melalui jaringan tanpa memerlukan interaksi manusia ke manusia atau manusia ke komputer. Internet of Things dapat didefinisikan sebagai subjek misalkan orang dengan monitor implant jantung, hewan peternakan dengan transponder biochip, sebuah mobil yang telah dilengkapi built-in sensor untuk memperingatkan pengemudi ketika tekanan ban rendah. Sejauh ini, IoT paling erat hubungannya dengan komunikasi machine-to-machine (M2M) di bidang manufaktur dan listrik, perminyakan, dan gas. Produk dibangun dengan kemampuan komunikasi M2M yang sering disebut dengan sistem cerdas atau "smart". (contoh: smart label, smart meter, smart grid sensor)[1].

\section{NodeMCU}

NodeMCU adalah sebuah platform IoT yang bersifat opensource. Terdiri dari perangkat keras berupa System On Chip ESP8266 dari ESP8266 buatan Espressif System, juga firmware yang digunakan, yang menggunakan bahasa pemrograman 
scripting Lua. Istilah NodeMCU secara default sebenarnya mengacu pada firmware yang digunakan daripada perangkat keras development kit. [2] Gambar NodeMCU terlihat pada gambar 1

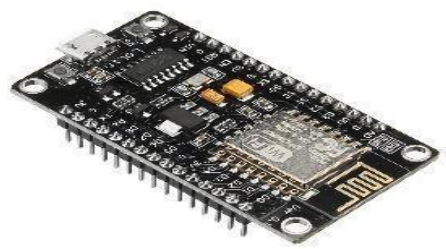

Gambar 1. NodeMCU

\section{Sensor Ultrasonik}

Sensor Ultrasonik adalah alat sensor yang digunakan oleh sistem yang berfungsi untuk mengubah besaran fisis (bunyi) menjadi besaran listrik dan sebaliknya. Cara kerja sensor ini didasarkan pada prinsip dari pantulan suatu gelombang suara sehingga dapat dipakai untuk menafsirkan eksistensi (jarak) suatu benda dengan frekuensi tertentu. Fungsi: mengukur volume suatu tangki air berdasarkan jarak dari tutup tangki ke dasar air yang ada sehingga dapat diketahui kapasitas tangki air tersebut. [4]

\section{Relay Modul}

Relay merupakan jenis komponen elektronika yang berfungsi sebagai saklar elektris. Sama dengan saklar pada umumnya, yang membedakan hanya pada sistem kerja. Relay bekerja jika dialiri dengan arus listrik rendah, maka relay akan memutuskan arus yang mengalir ke suatu perangkat.[4] Gambar relay modul terlihat pada gambar 2

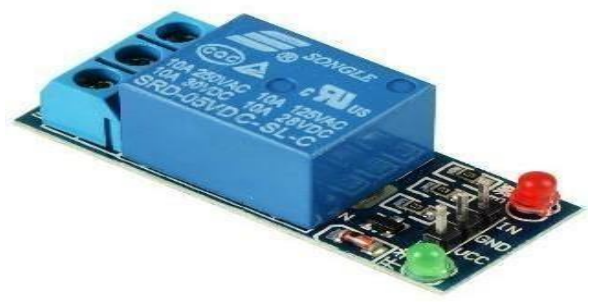

Gambar 2. Relay Modul

\section{Pompa Air DC}

Pompa adalah suatu alat yang berfungsi untuk mengalirkan, memindahkan dan mensirkulasikan zat cair incrompessible dengan cara menaikkan tekanan dan kecepatan dari suatu tempat ke tempat lain, atau dengan kata lain pompa adalah alat yang merubah energi mekanik dari suatu alat penggerak menjadi energi potensial yang berupa head, sehingga zat cair tersebut memiliki tekanan sesuai dengan head yang dimilikinya.[5]

Micro USB merupakan kabel yang digunakan untuk menghubungkan perangkat satu dengan yang lain nya, begitupun pada nodemcu dibutuhkan kabel untuk menghubungkan nya ke suatu perangkat agar bisa di konfigurasi dan berjalan sesuai perintah yang di

\section{METODOLOGI}

Adapun tahapan yang akan dilakukan pada alat monitoring kapasitas air pada tangki air cuci tangan berbasis nodemcu menggunakan aplikasi telegram adalah sebagai berikut :

Objek Pengujian

Tahapan ini bertujuan untuk memilih objek dari pengujian. Objek Pengujian alat ini merupakan tangki air cuci tangan di Politeknik Negeri Padang.

\section{Studi Pustaka}

Tahapan ini bertujuan untuk mencari beberapa sumber tertulis yang berhubungan dengan masalah yang dibahas.

\section{Analisis Kebutuhan}

Tahapan ini merupakan tahapan untuk menganalisa kebutuhan alat agar dapat dipahami seperti apa yang dibutuhkan oleh user. Sistem yang dibuat merupakan embedded sistem berbasis IoT yang terdiri dari beberapa komponenya yaitu NodeMCU ESP8266, sensor 
Ultrasonik, LCD 16x2, Relay, Buzzer, Mini Pump, LED dan aplikasi Android yang saling terintegrasi. Ini dimanfaatkan untuk meningkatkan sistem monitoring kapasitas tangki air. Sistem ini berfungsi untuk mendeteksi kekurangan atau kelebihan pada kapasitas tangki air. Kemampuan berinteraksi pada pengguna dengan mengaktifkan aplikasi Android mendapatkan informasi jarak air pada tangki, status air, status alarm, dan status pompa pada tangki air, maka aplikasi Android akan mengeluarkan notifikasi supaya segera mengisi air pada tangki.

Dalam melakukan proses pembuatan alat kontrol automatis dibutuhkan beberapa hardware untuk mendukung agar sistem kontrol berjalan sesuai keinginan

Proses pembuatan sistem alat kontrol menggunakan software Arduino IDE dengan bahasa pemrograman $\mathrm{C}$. Sistem monitoring berbasis aplikasi Android menggunakan software Telegram.

\section{HASIL DAN PEMBAHASAN}

Perancangan Alat

Pada tahapan ini, di tuangkan ide pemikiran untuk prinsip kerja alat dan dilakukan perancangan sistem agar alat dapat digunakan secara nyaman untuk diujikan ${ }^{3}$ pada tangki air.Perancangan tangki ini dibentuk prototype seperti tabung yang tingginya $20 \mathrm{~cm}$ dan diameter $22 \mathrm{~cm}$, untuk volume tabung maximal $(100 \%)$ adalah 7598,8 dan volume minimalnya $(0 \%)$ adalah 0 , untuk menghidupkan mesin pompa air volume air setidaknya ketinggian air kurang dari $6 \mathrm{~cm}$ $(30 \%)$ dan untuk mematikan air setidaknya ketinggian air lebih dari $17 \mathrm{~cm}(85 \%)$ Tangki air juga dilengkapi dengan kran serta gerbang air di atas tabung. Dengan menggunakan pompa untuk mengalirkan air dari sumber air. Berikut gambar rancangan tangki air pada Gambar 3

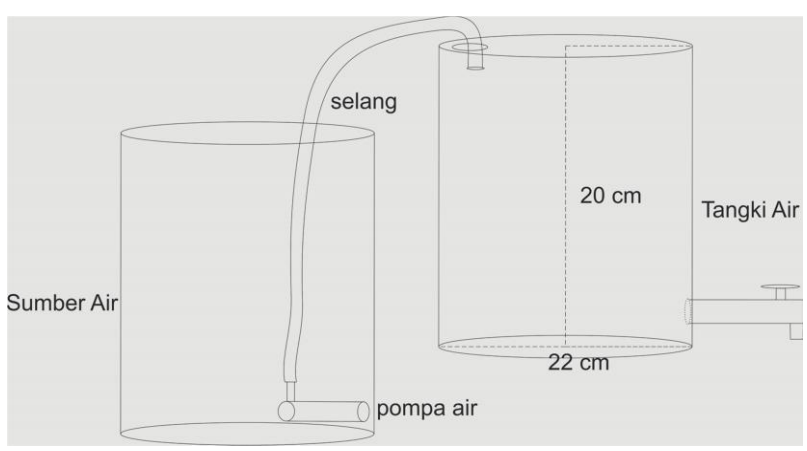

Gambar 3. Rancangan Tangi air Konfigurasi pin dari

Perangkat keras yang akan digunakan untuk membuat prototype sistem monitoring volume pada tangki berbasis android menggunakan mikrokontroler nodemcu, sensor ultrasonik, sensor kekeruhan, relay, pompa air 9V.

Berikut ini gambaran tentang block program yang digunakan dalam penelitian ini:

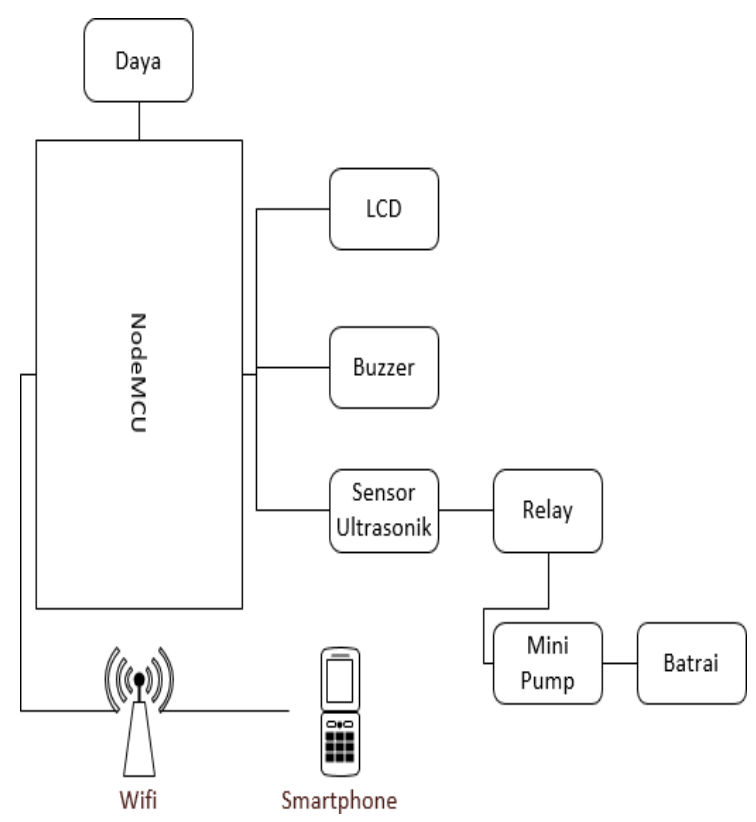

Gambar 4. Block diagram penelitian

Dibawah ini akan dijelaskan masingmasing fungsi dari setiap bagian diagram diatas:

1. Daya, berfungsi untuk mengalirkan aliran listrik ke dalam mikrokontroller.

2. Mikrokontroller Nodemcu,berfungsi untuk memproses data yang diterima 
dari input seperti sensor ultrasonik, buzzer, lcd, relay, dan mini pump.

4. LCD berfungsi untuk memberi peringatan kapasitas tangki air.

5. Buzzer berfungsi sebagai peringatan (bunyi) padad kapasitas tangki air.

6. Sensor Ultrasonik berfungsi untuk mengukur ketinggian air yang terdapat pada tangki air.

7. Relay berfungsi sebagai menghidupkan /mematikan pompa air pada tangki air.

8. Mini Pump berfungsi untuk memompakan aliran air ke dalam tangki air.

9. Baterai berfungsi sebagai daya untuk mini pump agar mini pump dapat bekerja maksimal.

10. Wifi berfungsi sebagai menyambung kan antara mikrokontroller, smartphone, dan keseluruhan komponen yang terdapat.

11. Smartphone berfungsi untuk menerima notifikasi kapasitas pada tangki air.

\section{Flowchart berfungsi sebagai pedoman dalam penyusunan dan pengembahan dari sebuah sistem yang akan dibangun. Flowchart juga dapat digunakan untuk melihat alur/proses dari sistem sebuah program.}

Flowchart alat monitoring kapasitas tangki air menggambarkan alur proses penggunaan alat mikrokontroler untuk user melakukan monitoring pada sebuah tangki air. Pada proses monitoring, alat akan melakukan pengecekan data kapasitas tangki yang dikirim dengan data yang sudah di deteksi oleh sensor ultrasonik. Seperti yang dapat dilihat pada gambar dibawah ini:

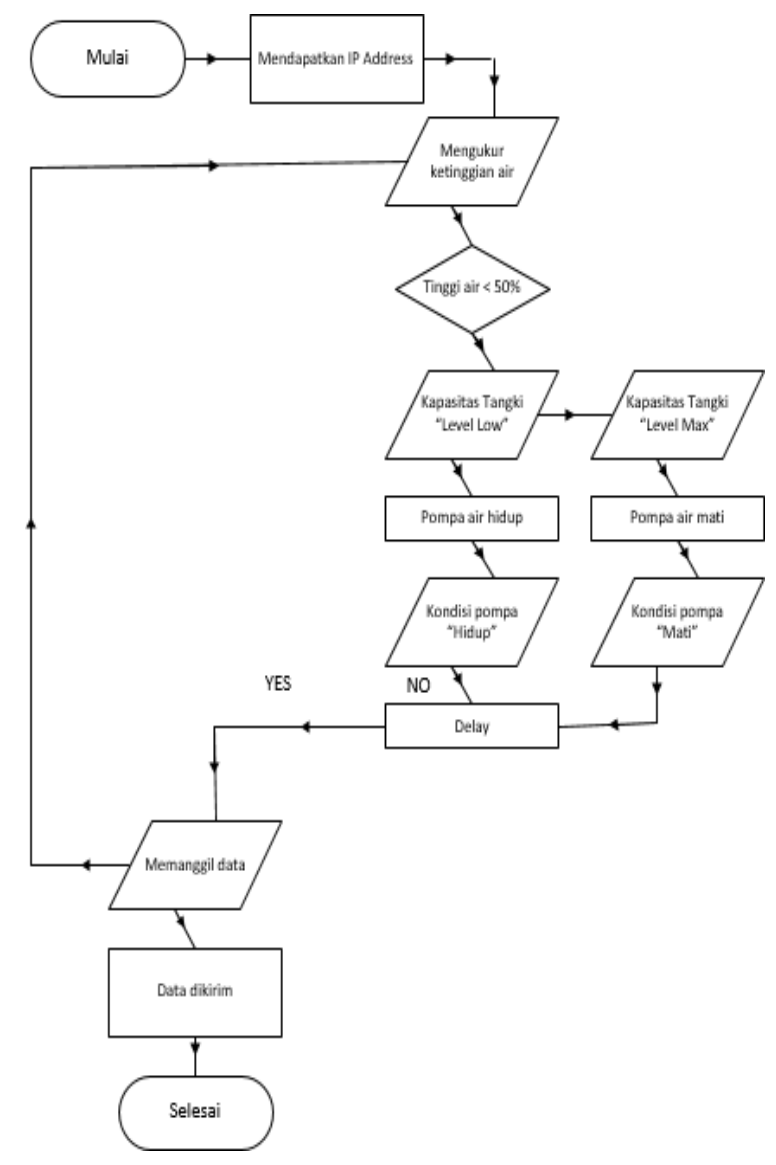

Gambar 5. Flowchart

Pembuatan Kode Program

Tahapan ini berguna untuk menerjemahkan desain perancangan alat kedalam bahasa pemrograman. Hasil dari tahapan ini adalah program komputer yang sesuai dengan desain yang telah dibuat pada tahap sebelumnya.

Berikut ini merupakan source code yang digunakan untuk berkomunikasi dengan Arduino Uno dengan sensor-sensor serta relay module mengunakan aplikasi Arduino IDE.

Membuat Source Code library

\#ifdef

ESP32 //

library

untuk

ESP32

\#include

<WiFi.h>

\#else 
\#include <ESP8266WiFi.h>

\#include

$<$ WiFiClientSecure.h> //

library client ke telegram

\#include

<UniversalTelegramBot.h> //

library koneksi nodemcu ke

telegram

\#include <ArduinoJson.h> //

library untk interface api/token

ke telegram

\#include <LiquidCrystal_I2C.h>// library

lcd

Pada \#include <ESP8266WiFi.h>

merupakan deklarasi library board

nodemcu yang telah di download

pada web, kemudian

\#include <WiFiClientSecure.h>

merupakan deklarasi library client ke telegram, \#include <ArduinoJson.h> merupakan deklarasi library untuk token pada telegram.

Membuat Source Code Sensor Ultrasonik \#define trigpin D3 // deklarasi pin digital 3 untuk trigger sensor ultrasonik ke nodemcu \#define echopin D0 // deklarasi pin digital 0 untuk echo sensor ultrasonik ke nodemcu

String getReadings ()\{ //function untuk mengirim data sensor ke telegram

int duration, distance; // inisialiasai tipe data untuk sensor ultrasonic

\section{SIMPULAN}

Dari pembahasan dapat diambil kesimpulan dari penelitian ini sebagai berikut.

1. Dengan adanya alat monitoring kapasitas tangki air dapat dilakukan pengecekan secara berkala melalui smartphone petugas ataupun pengecekan secara manual melalui sisi luar pada tangki menggunakan lcd yang terpasang.

2. Implementasi alat monitoring kapasitas tangki air berhasil dilakukan dengan menggunakan mikrokontroler NodeMCU dan sensor Ultrasonic sebagai alat untuk mengukur ketinggian air di dalam tangki.

3. Apabila kapasitas tangki air berada pada level 20\% maka alarm buzzer akan berbunyi hingga melebihi kapasitas tangki air diatas $20 \%$ hingga buzzer tersebut mati dengan sendiri nya, dan pengecekan secara manual dapat dilihat melalui lcd dan lampu indikator led yang menyala.

4. Kendala pengisian air dapat diberitahukan kepada pengguna lewat aplikasi dengan menggunakan fitur notifikasi apabila nilai status_air kurang atau bernilai $20 \%$.

\section{SARAN}

Adapun saran yang diberikan untuk pengembangan penelitian ini adalah.

1. Terdapatnya data error pada perhitungan pertama di NodeMCU sehingga diharapkan untuk penelitian selanjutnya dapat memperbaiki serta mengembangkannya.

2. Letak komponen dan nodemcu di atas tangki air masih terlihat belum rapi dan resiko kerusakan komponen masih besar diharapkan penelitian selanjutnya dapat memberikan kotak atau pelindung yang berisikan komponen sehingga dapat mengurangi resiko kerusakan.

3. Tidak konsistennya output sensor air sehingga diharapkan penelitian selanjutnya dapat memperbaiki serta mengembangkanya.

4. Kecepatan air yang masuk serta keluarnya air dari tangki air belum diketahui, sehingga diharapkan untuk penelitian selanjutnya melakukan 
pengembangan dari komponen tangki air dan nodemcu.

5. Tangki air yang berbentuk tabung bentuknya belum sesuai yang diinginkan diharapkan penelitian selanjutnya dapat membuat tangki air yang lebih baik.

\section{DAFTAR PUSTAKA}

[1] Yudhanto, Yudha (2007) : Apa Itu IoT (Internet Of Thinks) : Ilmu Komputer.com.

[2] NodeMCU Documentation. Diakses tanggal 17 April 2016 dari www.nodemcu.com.

[3] Pengertian USB (Universal Serial Bus) dan Jenis-jenis Konektor USB, diakses pada tanggal 13 Agustus 2020, dari word wide web : http://teknikelektronika.com

[4] Ananda.ricki (2018) : 40 Project .Robotik \& Aplikasi Android. Yogyakarta: deepublish.

[5] Wijayata, I wayan Arta. (2014): Pemanfaat Energi Surya untuk Menggerakan Pompa Motor DC Yang Dikontrol Mikrokontroler ATmega8535. Bali : Universitas Udayana

[6] 1602 LCD with I2C interface Datasheet, diakses pada tanggal 26 Juli 2020, dari word wide web: http://circuitattic.com

[7] Wijayono, Andrian (2017) : Rancang Bangun Alat Pengukur Diameter Benang Dengan Perangkat Digital Microscope Dan Aplikasi Pengolah Citra Digital Berbasis Java : Bandung.

[8] Satyaputra, Alfa dan Eva Maulina Aritonang (2014) : Beginning Android Programing With ADT Bundle .Jakarta :PT.Elex Media Komputindo.
[9] Apa itu Telegram, diakses pada tanggal 14 Agustus 2020, dari word wide web: http://utopicomputers.com

[10] Sitorus, Lamhot (2015): Algoritma dan Pemograman, Yogyakarta: ANDI

[11] Adhitya Permana dan Dedi Triyanto dkk. Rancang Bangun Sistem Monitoring Volume Dan Pengisian Air Menggunakan Sensor Ultrasonik Berbasis Mikrokontroler Avr Atmega8.

[12] Abdul Fattah M dan Goib wiranto dkk. Rancang bangun sistem alat ukur turbidity untuk analisis kualitas air berbasis Arduino. 